Article

\title{
Population Genetic Diversity of Quercus ilex subsp. ballota (Desf.) Samp. Reveals Divergence in Recent and Evolutionary Migration Rates in the Spanish Dehesas
}

\author{
Angel Fernández i Marti ${ }^{1}$, Cristina Romero-Rodríguez ${ }^{2}$, Rafael M. Navarro-Cerrillo ${ }^{3}$ (i), \\ Nieves Abril ${ }^{2}$ (1) , Jesús V. Jorrín-Novo ${ }^{3}$ and Richard S. Dodd ${ }^{1, *}$ \\ 1 Department of Environmental Science, Policy and Management, University of California Berkeley, \\ Berkeley, CA 94720, USA; afernandezmarti@berkeley.edu \\ 2 Agroforestry and Plant Biochemistry, Proteomics and Systems Biology, 14014 Cordoba, Spain; \\ mcrr.84@gmail.com (C.R.-R.); bb1abdim@uco.es (N.A.) \\ 3 Evaluation and Restoration of Agricultural and Forestry Systems, Research Groups, University of Cordoba, \\ UCO-CeiA3, 14014 Córdoba, Spain; rmnavarro@uco.es (R.M.N.-C.); bf1jonoj@uco.es (J.V.J.-N.) \\ * Correspondence: dodd@berkeley.edu
}

Received: 3 April 2018; Accepted: 4 June 2018; Published: 7 June 2018

\begin{abstract}
The Spanish dehesas have been severely affected by human activities that date to the prehistoric period and have suffered accelerated decline since the 1980s. Holm oak (Quercus ilex subsp. ballota (Desf.) Samp.) is a key component of this system, and its acorns provide an important food source for wildlife and domesticated livestock. Our earlier work showed structured variation in acorn morphology and biochemistry. Here, we used chloroplast and nuclear microsatellites to detect genetic structure among populations of $Q$. ilex from the major biogeographic regions of Andalusia. We found high levels of spatial differentiation with chloroplast DNA indicating little seed dispersal among populations. Spatial differentiation was weaker for nuclear DNA, presumably as a result of more widespread pollen dispersal and its larger effective population size. The Baetic Cordillera (Cádiz) population consistently appeared well separated from populations of the northern Sierra Morena, suggesting that the Guadalquivir Valley has played an important role in determining population divergence. This may be, in part, evolutionary, as suggested by chloroplast DNA, and, in part, a result of human-induced population isolation, as $Q$. ilex has been removed from the Guadalquivir Valley. Evolutionary gene flow rates were greater than contemporary rates, which were limited to unidirectional gene flow from Córdoba to other populations in the Sierra Morena and, surprisingly, to the southern population at Almería. The inconsistency between evolutionary and recent migration rates suggests an effect of anthropogenic activity over the last few generations of Q. ilex.
\end{abstract}

Keywords: Quercus ilex; dehesas; population structure; genetic divergence; gene flow; nSSR; cpSSR

\section{Introduction}

Holm oak (Quercus ilex subsp. ballota (Desf.) Samp.) is the dominant tree species in natural forest ecosystems over large areas of the western Mediterranean Basin and is the distinctive element of the Spanish agrosilvopastoral ecosystem "dehesa". Both holm oak natural forest and the dehesa are seriously threatened by several factors, the most important of which are of anthropogenic origin: overexploitation, poor management practices, and fire, as well as diseases and adverse environmental conditions [1]. These have contributed to a severe decline observed since the early 1980s [2,3]. Lack of 
regeneration that has led to populations dominated by aging individuals is one of the greatest threats to these ecosystems and is likely to become more problematic under anticipated climate change, with high temperatures and severe drought episodes expected for southern Spain and other Mediterranean countries $[4,5]$.

Forest restoration and reforestation as well as sustainable management were major objectives for the afforestation programs implemented in Spain at the end of the 20th century and the beginning of the 21st, promoted by the European Union which established a Community aid scheme for forestry measures in agriculture lands [6]. Q. ilex has become a priority species to achieve these objectives. The ultimate goal requires the selection of "elite" genotypes in terms of higher germination rates, increased acorn production, and desirable quality traits related to nutritional values, as well as adaptation to adverse biotic and abiotic stresses. This selection should be directed by phenotypic, physiological, and molecular analyses. Our group is carrying out a project in which variability in a number of traits in Andalusian holm oak populations is being analyzed. At the phenotypic level, we have shown the existence of differences in tolerance to drought stress and resistance to Phytophthora cinnamomi Rands infection among populations from different geographical locations; the differential response has been characterized at the physiological (water status and photosynthesis) and proteomic levels [7-9]. In an attempt to analyze variability and differences among provenances of holm oak from Andalusia, acorn morphometry and Near infrared reflectance spectroscopy (NIRS) chemical analysis as well as protein profiling in pollen and acorns were performed [10-12]. We found high levels of variability within and between populations. Although spatial grouping of populations was evident, spatially intermediate populations clustered differently according to the analysis employed (NIRS or proteomics), raising the question as to what extent population genetic structure can explain spatial variations in these phenotypic traits.

Here, we use molecular data to investigate whether regional structure that might be associated with past and contemporary gene flow can be detected. Any observed genetic structure would then form the basis for strategies for the selection of phenotypic traits and, possibly, the selection of seed sources for planting. High genetic diversity is expected for holm oak considering its very long life; fecundity, allogamous, and anemophilous reproductive traits; and promiscuity and long history of introgression with other species [4,12-14]. We hypothesize that genetic structure among populations within Andalusia could be significant because of its importance as a glacial refugium. For many species, the current spatial structure of genetic diversity is determined, in part, by past climatic changes that have led to population shifts or by demographic changes [15]. The Iberian Peninsula is considered an important glacial refugial region within Europe [16,17]. Several phylogeographic studies have shown complex patterns of sub-refugia within the Iberian Peninsula [18], of which the Baetic Cordillera recurs as a sub-refugium for a wide range of taxa, including tree species [19-22]. A chloroplast phylogeography of $Q$. ilex revealed a unique chlorotype from southern Andalusia, suggesting an ancient refugial location [23]. However, a multi-marker genetic study of the Iberian Peninsula suggested widespread gene flow in $Q$. ilex, with relatively little differentiation [13]. Paleoclimate modeling of southern Spain has indicated that it was likely composed of multiple upland climatic refugia within the Baetic Cordillera and the Sierra Morena that could have been sites for species with different habitat requirements [24].

In view of the possibility of divergence among populations of $Q$. ilex in Andalusia and the likely partial genetic basis of our previously observed chemical composition and protein profiles [25], we undertook a molecular genetic study of populations of $Q$. ilex from the major regions of Andalusia. We performed nuclear and chloroplastic microsatellite analyses on 94 holm oak individuals from five natural populations distributed across bioclimatic gradients in the Andalusian territory. Our objectives in this research were to (1) determine levels of divergence among populations across Andalusia, (2) estimate differences in migration at an evolutionary and contemporary scale as well as the role of population bottlenecks on genetic diversity among the regions within Andalusia, and (3) assess 
whether differences in morphological and biochemical traits that we have previously reported are associated with genetic divergence and gene flow within the region.

\section{Materials and Methods}

\subsection{Populations, Plant Material, and DNA Extraction}

The present study was performed with five populations covering the major bioclimatic regions of Andalusia, southern Spain: Southeast (SAA: Almería), Southwest (BCA: Cádiz), Northeast (PCO: Córdoba), and Northwest (APS: Seville, CTH Huelva) (Figure 1 and Figure S3; Table 1). Andalusia is characterized by two west-east trending mountain ranges: the Sierra Morena in the north and the Baetic Cordillera in the south (the latter composed of a Mediterranean coastal range, the Cordillera Penibética, and an inner range, the Cordillera Subbética). The two major chains are separated by a broad central depression, the Guadalquivir Basin. Today, Q. ilex occupies low to mid-elevations in the two major mountain ranges, northern and southern populations being separated by the Guadalquivir Basin. Geographical coordinates, altitude, climatic data, and soil characteristics of each surveyed area are shown in Table 1. Twenty individuals were sampled from each locality; however, for two localities, poor DNA amplifications resulted in fewer samples being analyzed (see Table 1 for sample sizes). Trees were sampled across the landscape to minimize the likelihood of relatedness through seed, and no trees were sampled that were less than $10 \mathrm{~m}$ apart.

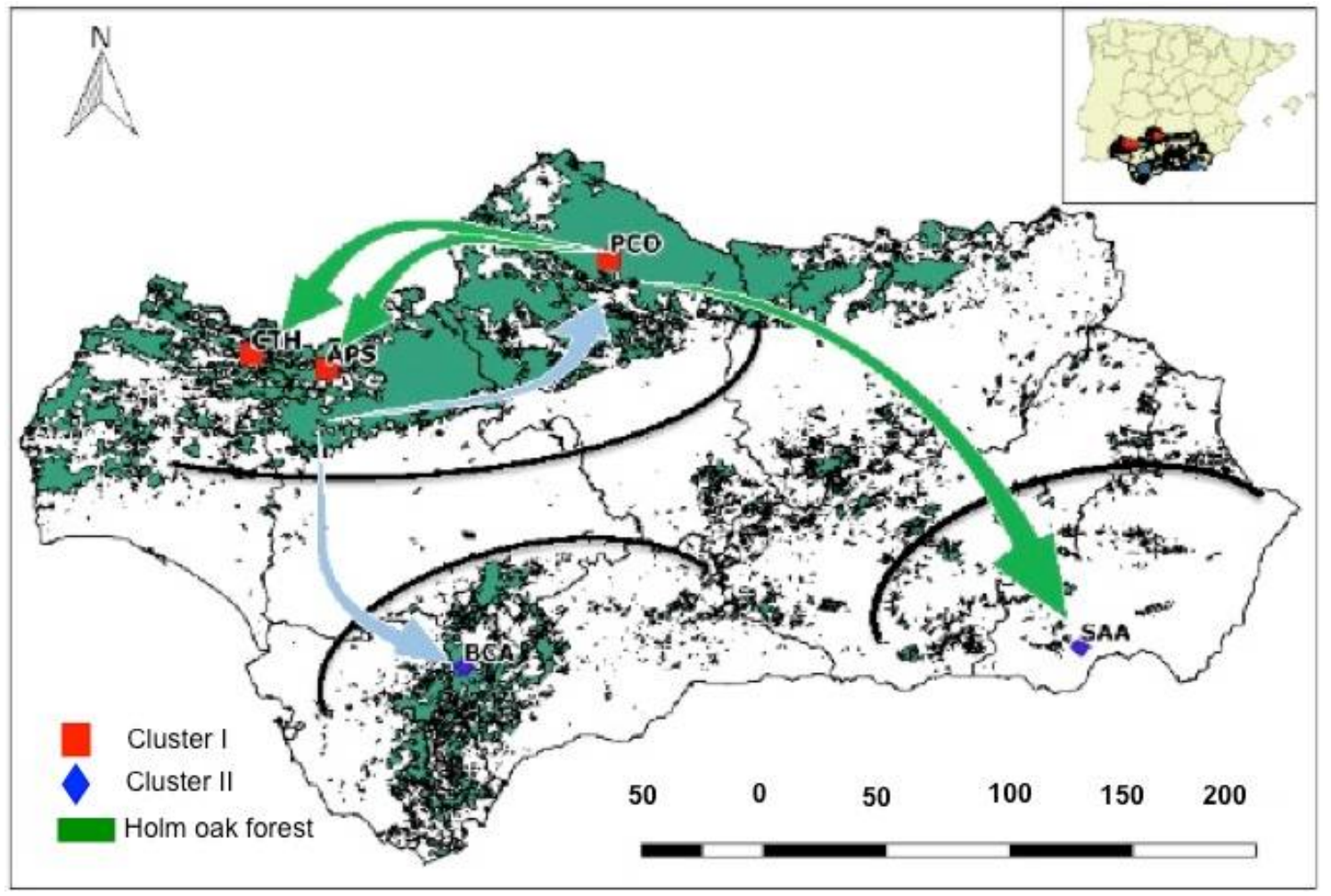

Figure 1. Map of Andalusia (inset showing position of Andalusia in Spain) showing the distribution of holm oak forest and sampling locations (see Table 1 for population codes). Blue arrows indicate inferred seed dispersal events on basis of chloroplast DNA; green arrows show significant recent directional gene flow (see text). Black curved lines partition populations following Barrier analyses. 
Table 1. Geographical and climatic data of the population of Quercus ilex subsp. ballota included in this study.

\begin{tabular}{|c|c|c|c|c|c|c|c|c|c|c|}
\hline Site & Code & Sample Size & Latitude $\left({ }^{\circ} \mathbf{N}\right)$ & Longitude $\left({ }^{\circ} \mathbf{W}\right)$ & Altitude (m) & $\begin{array}{c}\text { Annual } \\
\text { Precipitation } \\
\text { (mm) }\end{array}$ & $\begin{array}{c}\text { Mean Winter } \\
\text { Precipitation }(\mathrm{mm})\end{array}$ & $\begin{array}{c}\text { Mean Autumn } \\
\text { Precipitation }(\mathrm{mm})\end{array}$ & $\begin{array}{l}\text { Mean Monthly } \\
\text { Maximum } \\
\text { Temperature }\left({ }^{\circ} \mathrm{C}\right)\end{array}$ & $\begin{array}{l}\text { Mean Monthly } \\
\text { Minimum } \\
\text { Temperature }\left({ }^{\circ} \mathrm{C}\right)\end{array}$ \\
\hline Cádiz & BCA & 15 & 36.756628 & 5.452958 & 649 & 1263.6 & 375.1 & 408.9 & 24.9 & 9.8 \\
\hline Almería & SAA & 20 & 36.858483 & 2.478264 & 1241 & 277.9 & 248.5 & 103.4 & 25.2 & 8.9 \\
\hline Huelva & СТH & 19 & 37.919931 & 6.475167 & 364 & 845.6 & 310.2 & 348.4 & 26.3 & 9.5 \\
\hline Córdoba & $\mathrm{PCO}$ & 20 & 38.324489 & 4.827869 & 618 & 612.6 & 211.7 & 229.9 & 26.8 & 8.1 \\
\hline Seville & APS & 20 & 37.875678 & 6.474586 & 482 & 722.1 & 78.9 & 307.6 & 26.4 & 9.5 \\
\hline
\end{tabular}


For DNA extraction, a few leaf samples were collected from young shoots from the upper part of each tree, transported to the laboratory on ice, abundantly washed with tap water, blot dried, frozen in liquid nitrogen, and stored at $-80^{\circ} \mathrm{C}$. Genomic DNA was isolated following the protocol reported by Echevarria-Zomeño [26] and diluted to $10 \mathrm{ng} \mu \mathrm{L}^{-1}$ to carry out PCR amplifications.

\subsection{Nuclear and Chloroplast Microsatellite Analysis}

Ten nuclear microsatellites (SSR) and 10 chloroplast SSR markers (Table S1) previously developed from other species, including Q. macrocarpa Michx., Q. robur L., Q. petraea (Matt.) Lieb., and Castanea sativa Mill., were screened in the populations collected in this study. PCR was performed in a $20 \mu \mathrm{L}$ volume, with the reaction mixture containing $1 \times$ PCR buffer (Biotools, Madrid, Spain), $2 \mathrm{mM} \mathrm{MgCl} 2,0.2 \mathrm{mM}$ dNTPs, $0.5 \mu \mathrm{M}$ of each primer, 0.5 units Taq DNA polymerase (Biotools, Madrid, Spain), and $30 \mathrm{ng}$ of DNA. Amplifications were conducted as follows: 1 cycle of $3 \mathrm{~min}$ at $95^{\circ} \mathrm{C}$, followed by 35 cycles of $1 \mathrm{~min}$ at $94{ }^{\circ} \mathrm{C}, 45 \mathrm{~s}$ at the annealing temperature indicated in Table S1 for each primer, and $1 \mathrm{~min}$ at $72{ }^{\circ} \mathrm{C}$, followed by a final incubation of $7 \mathrm{~min}$ at $72{ }^{\circ} \mathrm{C}$. The PCR reactions were carried out in a 96-well block thermal cycler (Applied Biosystems, Madrid, Spain). PCR products were detected using an ABI PRISM 3130xl Genetic Analyzer and GeneMapper analysis software (Applied Biosystems, CA, USA). For capillary electrophoresis detection, forward SSR primers were labeled with the $5^{\prime}$ fluorescence dyes PET, NED, VIC, and 6-FAM, and the size standard used in the sequencer was Gene Scan 500 Liz (Applied Biosystems, CA, USA). Because of irregular amplification, the nuclear microsatellite locus, QpZAG9, was dropped from the analyses.

\subsection{Data Analysis}

\subsubsection{Chloroplast DNA}

Chloroplasts are inherited maternally without recombination in oaks; thus microsatellite variants were combined into haplotypes, whereby each haplotype was considered to be inherited as a single allele. We estimated within-population haplotype diversity $\left({ }_{\mathrm{cp}} H_{\mathrm{S}}\right)$, overall haplotype diversity $\left({ }_{\mathrm{cp}} H_{\mathrm{T}}\right)$, global among-population differentiation by allele identity $\left({ }_{\mathrm{cp}} G_{\mathrm{ST}}\right)$, and global among-population differentiation considering the allele size $\left({ }_{\mathrm{cp}} R_{\mathrm{ST}}\right)$ using PERMUT software (Petit et al., 2002 [21]). We also used PERMUT to test if the observed ${ }_{\mathrm{cp}} R_{\mathrm{ST}}$ value was significantly different from ${ }_{\mathrm{cp}} G_{\mathrm{ST}}$. This test is used to detect phylogeographic patterns (i.e., whether mutation has contributed significantly to population differentiation).

To explore divergence among haplotypes and their sharing among populations that would indicate evolutionary levels of successful seed migration, we constructed a haplotype network using the median-joining (MJ) network algorithm [27]. MJ networks were post-processed with a maximum-parsimony (MP) algorithm [28] to remove unnecessary linkages and median vectors. Network construction was performed in NETWORK 5.0.0.1 (available as freeware from http:/ / www. fluxus-engineering.com/sharenet.htm).

\subsubsection{Nuclear DNA}

We tested for null alleles using MICRODROP [29]. MICRODROP uses an expectationmaximization algorithm to obtain joint estimates of allele frequencies, drop-out rates caused by sample factors, and locus factors and inbreeding coefficients to correct for deficits in heterozygosity. The software can provide imputed datasets by drawing genotypes according to the posterior distribution of the model and replacing false homozygotes by heterozygotes. We performed MICRODROP imputations separately by population. We tested for deviations from Hardy-Weinberg (HW) equilibrium within each population by the inbreeding fixation index $F_{\mathrm{IS}}$ with the software FSTAT, version 2.9.3.2 [30]. We estimated allelic richness with the rarefaction method $\left(R_{\mathrm{t}}\right)$ and expected heterozygosity $\left(H_{\mathrm{e}}\right)$ with FSTAT to analyze the level of within-population genetic diversity. 
Population bottlenecks result in a transient disequilibrium by reducing allelic diversity through preferential loss of rare alleles, before having an effect on heterozygosity. We used BOTTLENECK 5.1 [31] to test for a signal of a bottleneck in all sampled oak populations under the two-phase model (TPM) with the default 70\% single-step mutations and 30\% multiple-step mutations. The TPM is an intermediate between the infinite allele model and the stepwise mutation model and is likely closer to the true mutation model of most microsatellites [31]. Statistical significance was tested with the one-tailed Wilcoxon signed-rank test to determine whether observed heterozygosity deviated from expectations at mutation-drift equilibrium. Estimations were based on 10,000 replications. Reductions in population size were also tested using the "mode-shift" indicator of the distortion of allele frequency classes' distributions. In non-bottlenecked populations, the mode-shift distribution should be approximately L-shaped with the greatest number of alleles being detected at low frequencies [31].

To infer population structure, we used a Bayesian model based approach performed in the program STRUCTURE, version 2.3.4 [32] and a model-free multivariate approach, discriminant analysis of principal components (DAPC) [33]. For STRUCTURE, an admixture model with correlated frequencies was used without prior population information. Preliminary runs revealed a complex hierarchical structure. We inferred population division (number of $K$ populations) by performing 20 independent runs of each $K(K=1$ to $K=5)$ with a burn-in of 100,000 iterations and 1 million iterations of the Gibbs sampler. Log-likelihood of the data was recorded for each run, and the ad hoc statistic $\Delta K$ was calculated following Evanno et al. [34]. Output from STRUCTURE was post-processed to obtain $\triangle K$ and plots for publication using the online program CLUMPAK [35].

For DAPC, discriminant analysis (DA) was used to identify clusters on the basis of data that were transformed using principal component analysis (PCA). The number of PCA axes that were retained for DA was determined by 30 replicates of cross-validation. DAPC was performed in R, using the Adegenet package [33].

We used Barrier 2.2 [36] to test for the most prominent breaks in nuclear microsatellite data. Barrier detects geographic barriers by testing the correlation between the geographic distance and genetic distance among sampling locations using the Monmonier algorithm. We performed the Barrier analysis with 100 distance matrices (shared alleles) from bootstrapped data obtained by MSA 4.05 [37].

\subsubsection{Inferring Migration}

We used BayesAss [38] to estimate contemporary migration among the five sampled populations. BayesAss uses a Bayesian multilocus approach in which populations are not constrained by stationary conditions, so that individual populations may be out of HW equilibrium. Bidirectional migration rates among all populations are inferred over the last generations by detecting transient disequilibrium among multilocus genotypes of migrants or recent descendants of migrants. In preliminary runs, we adjusted mixing parameters to obtain acceptance rates in the range $0.2-0.6(\Delta a=0.5, \Delta m=0.5$, and $\Delta f=0.7$ ). Final runs (five runs) were performed with different starting seeds, run for $10,000,000$ iterations with 1,000,000 burn-in, and averaged to provide estimates of migration rates. Convergence of the runs was assessed by examining plots of total log-likelihood versus iteration to verify that there were no peaks or troughs using TRACER 1.5 [39].

Because contemporary and evolutionary migration rates can provide complementary information on population demography, we also estimated evolutionary bidirectional migration among populations using Migrate-N. We evaluated three population models that took into account the biogeography of Andalusia and the clustering of our earlier results from morphometrics and acorn chemistry: Model 1: Full model with 5 population sizes and 20 bidirectional migration rates. Model 2a: Two-population model that followed our population groupings based on acorn morphometrics and fatty acid composition that showed separation between Sierra Morena populations (Huelva, Córdoba, and Seville) from Baetic populations (Cádiz and Almería) [11]. This model included two population sizes and two migration rates. Model 2b: Two-population model that followed our groupings based on acorn protein profiles that indicated separation of western Sierra Morena (Huelva and Seville) 
and central and eastern populations (Córdoba, Cádiz, and Almería) [10]. Model 2c: Two-population model inferred by STRUCTURE and Barrier results that suggested divergence of Cádiz from all other populations. Model 3: Three-population model. This model was based on biogeographic separation of the Sierra Morena populations (Huelva, Córdoba, and Seville) from Cordillera Penibética (Almería) and Cordillera Subbética (Cádiz) and included three population sizes and six migration rates. We used Bayesian inference (BI) to infer population $\theta \mathrm{s}\left(4 N_{e} \mu\right.$, where $N_{e}$ is effective population size and $\mu$ is the mutation rate) and mutation-scaled migration rates $(M=m / \mu$, where $m$ is the migration rate per generation). The Brownian motion model was used to approximate a stepwise mutation model for microsatellites. Initial runs were performed to determine appropriate priors that were set for final runs as uniform $(\theta$ of $0.00-10.00, \delta=1.0$ and $M$ of $0.00-1000.00, \delta=100.00)$. Each run comprised a single long chain for which $1 \times 10^{6}$ genealogies were sampled with a burn-in of $1 \times 10^{4}$ and static heating with default temperatures. Initial parameter values were obtained from estimates of $F_{\mathrm{ST}}$. We estimated probabilities for each model by dividing its marginal likelihood by the sum of the marginal likelihoods of all models using the Bézier approximation.

\section{Results}

\subsection{Chloroplast DNA}

We detected a total of 30 distinct haplotypes among the five regional populations (Figure 2). The total number of mutational steps among the haplotypes inferred from the shortest trees was 61 , with most individuals from the same population clustering together with few mutational steps, with the exception of Córdoba. The greatest number of haplotypes [9] was found at Córdoba, whereas we detected only five haplotypes each at Seville and Huelva, three of which were shared in the two populations (Figure 2). Other than the sharing between Seville and Huelva, the remaining populations comprised unique sets of haplotypes. The shared haplotypes at Seville and Huelva suggest recent seed dispersal between the two populations that could be bidirectional. However, interestingly, two individuals (one each from Cádiz and Córdoba) clustered with the Huelva/Seville group (one mutational step for the Cádiz individual and five mutational steps for the Córdoba individual), suggesting unidirectional historical seed dispersal from Huelva/Seville. The number of inferred mutational steps among individuals within populations averaged 7 each at Cádiz (excluding the one individual that clustered with Huelva/Seville) and Almería, 14 in the combined Huelva/Seville cluster, and 21 at Córdoba. Seven mutated positions were inferred between the Huelva/Seville cluster and the closest Córdoba chlorotype (excluding the one individual that clustered with Huelva/Seville), whereas three and four mutated positions were inferred between Córdoba and the nearest haplotypes from Almería and Seville, respectively.

Global among-population differentiation considering the allele size $\left({ }_{\mathrm{cp}} R_{\mathrm{ST}}=0.57 ; \mathrm{SE}=0.05\right)$ was significantly greater than among-population differentiation by allele identity $\left({ }_{\mathrm{cp}} G_{\mathrm{ST}}=0.24 ; \mathrm{SE}=0.05\right)$, indicating that mutation had contributed significantly to population differentiation. 


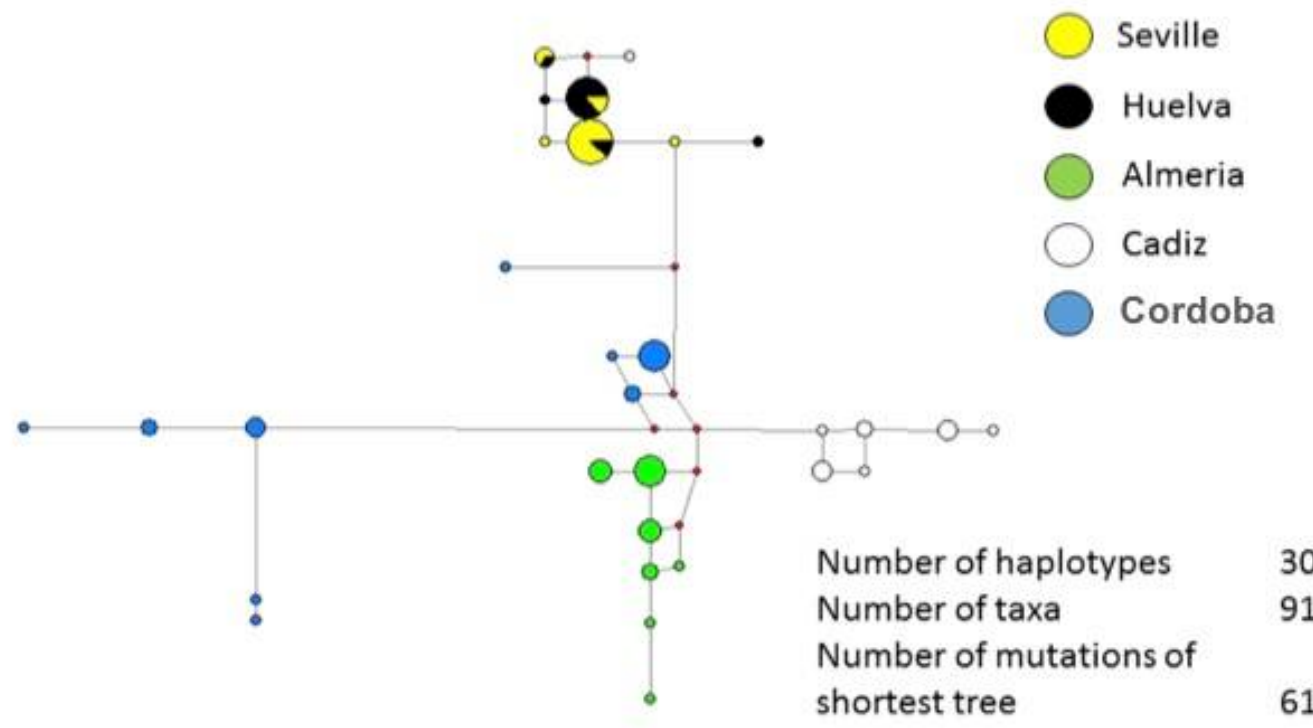

Figure 2. Haplotype network based on 10 chloroplast microsatellite loci produced in NETWORK 5.0.0.1. Size of circles is proportional to number of individuals, and pie shapes are the proportion of individuals from each of the five populations.

\subsection{Nuclear DNA}

Significant allelic dropout was detected by Microdrop for genotypes at Almería, Córdoba, and Seville. Of these, the Pearson correlation coefficient was significant across individuals at Córdoba and Seville and across loci at Almería. We imputed missing alleles for each population using the option in Microdrop in which both locus- and individual-specific factors are taken into account for imputed data sets. Inbreeding coefficients estimated for each population from the original data and the imputed data returned similar results; thus for the analyses reported here, we used the imputed dataset.

We detected a total of 101 alleles across populations at the nine microsatellite loci in $Q$. ilex. Allelic richness, on the basis of a minimum population size of 15, was least in Córdoba (5.5 alleles) and greatest in Huelva (7.3) (Table 2). Over all populations, we found negligible heterozygote excess $\left(H_{\mathrm{O}}=\right.$ $0.77 ; H_{\mathrm{E}}=0.71$ ); among populations, expected heterozygosity ranged from 0.68 to 0.72 but did not vary significantly (Table 2 ).

Table 2. Parameter estimates for chloroplast and nuclear microsatellite diversity in populations of $Q$. ilex from Andalusia, Spain. $H_{\mathrm{e}}$ - expected heterozygosity; $\mathrm{AR}_{15}$-number of alleles on basis of a minimum population size of $15 ; F_{\mathrm{IS}}$-inbreeding coefficient. Numbers in parentheses indicate standard errors of the estimates.

\begin{tabular}{cccccc}
\hline \multirow{2}{*}{ Population } & \multicolumn{2}{c}{ Chloroplast } & \multicolumn{3}{c}{ Nuclear } \\
\cline { 2 - 6 } & No. Haplotypes & $\boldsymbol{H}_{\mathbf{e}}$ & Mean No. Alleles per Locus & AR $_{\mathbf{1 5}}$ per Locus & $\boldsymbol{F}_{\mathbf{I S}}$ \\
\hline Cádiz & 7 & $0.71(0.07)$ & $6.2(0.9)$ & $6.2(0.9)$ & $-0.11(0.10)$ \\
Almería & 7 & $0.71(0.07)$ & $6.8(1.1)$ & $7.4(1.0)$ & $-0.11(0.12)$ \\
Huelva & 5 & $0.72(0.07)$ & $7.8(1.5)$ & $5.5(0.9)$ & $-0.03(0.05)$ \\
Córdoba & 9 & $0.68(0.07)$ & $5.8(1.0)$ & $7.0(1.0)$ & $-0.05(0.09)$ \\
Seville & 5 & $0.72(0.07)$ & $7.4(1.1)$ & $7.8(1.2)$ & $-0.05(0.08)$ \\
Total & 30 & $0.74(0.07)$ & $11.2(1.6)$ & $0.02(0.07)$ \\
\hline
\end{tabular}

\subsection{Past Demographic Change}

BOTTLENECK detected significant values of heterozygote excess, consistent with a recent bottleneck using the Cornuet and Luikart [40] test, in the population at Córdoba (probability of the one-tailed test of heterozygote excess of $<0.001$ ). Inspection of the mode-shift distributions showed weak signs of bottleneck effects in all populations but most evidently at Cádiz and Córdoba (Figure S1). 


\subsection{Population Structure}

The ad hoc statistic $\Delta K$, which summarizes our results from 10 independent runs per $K$ (from $K=1$ to $K=5$ ) in STRUCTURE, suggested that the microsatellite data on $Q$. ilex could be assigned to three clusters, as shown in Figure 3. Although the three clusters were admixed in individuals from the five populations, some population differentiation was clear. Cádiz and Almería were well differentiated from each other, whereas Huelva, Seville, and Córdoba were intermediately differentiated.

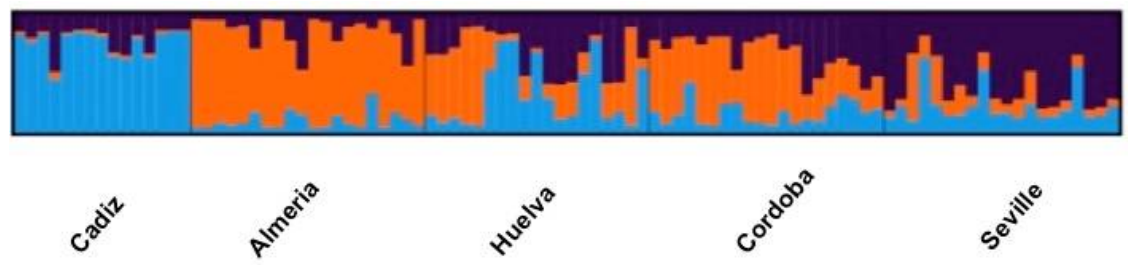

Figure 3. Plot of STRUCTURE results with $K=3$ of $Q$. ilex populations from Andalusia.

For the DAPC analyses, cross-validation indicated that 30 principal component (PC) axes and 4 DA axes were optimal. In the space of the first two DA axes, Cádiz and Almería populations were divergent from one another and from the remaining populations that grouped together as partially overlapping clusters (Figure 4).

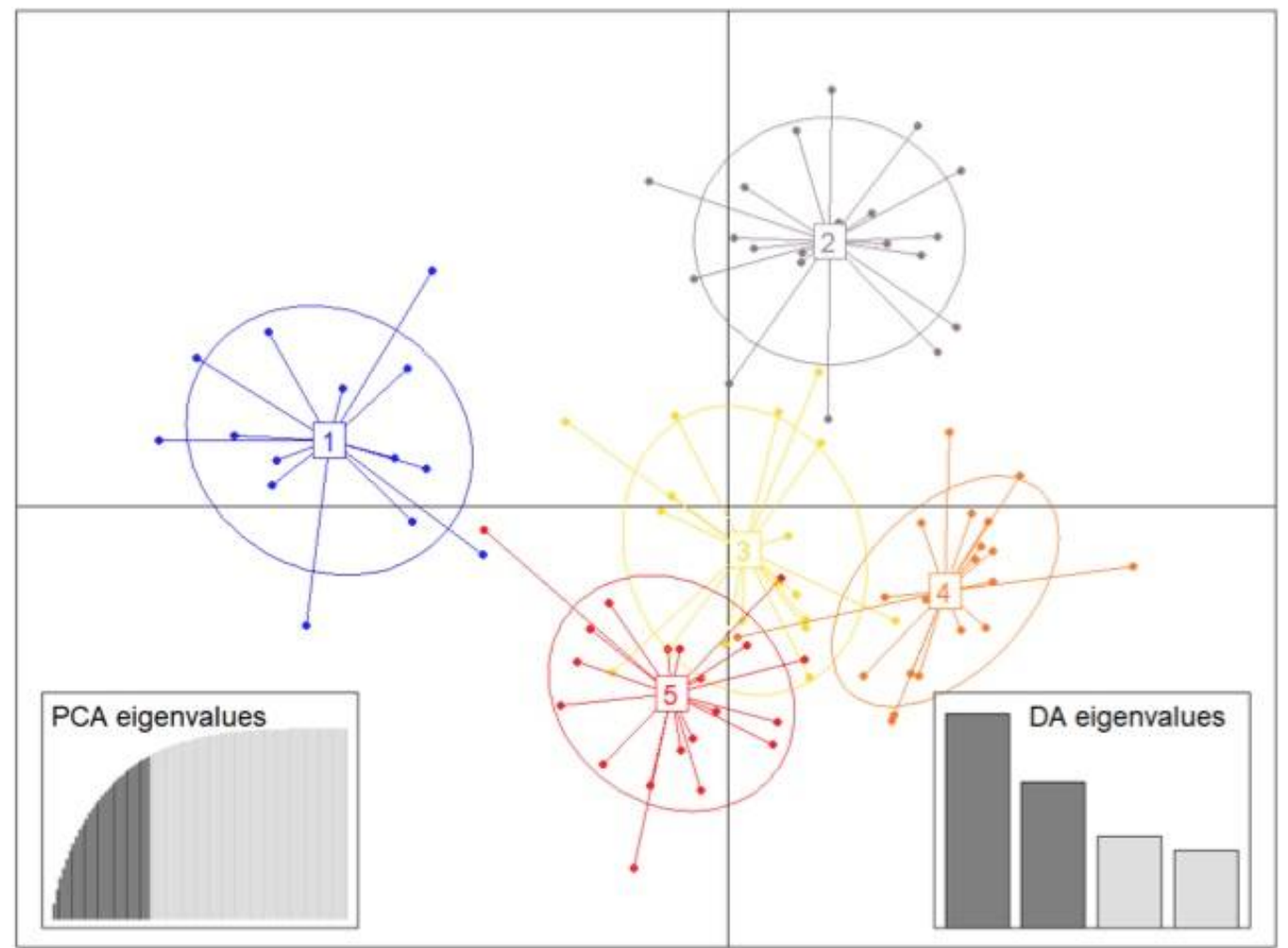

Figure 4. Discriminant analysis of principal components (DAPC) plot of five populations of Q. ilex from Andalusia (1-Cádiz; 2-Almería; 3-Huelva; 4-Córdoba; 5-Seville) on basis of 30 principal component analysis (PCA) components and 4 discriminant analysis (DA) axes.

A barrier of decreasing strength was detected by Barrier extending between Cádiz and Seville/Huelva, Cádiz and Córdoba, and Cádiz and Almería (Figure 1 and Figure S2). 


\subsection{Migration}

Significant contemporary migration rates estimated by BayesAss were detected from Córdoba to Almería (95\% CI: 0.19-0.33), Córdoba to Huelva (95\% CI: 0.18-0.32), and Córdoba to Seville (95\% CI: 0.06-0.18), for which mean rates are shown in bold in Table 3. All other population pairwise rates were not significantly different from zero, including the reciprocal rates into Córdoba, suggesting recent unidirectional gene flow.

Table 3. Migration rates estimated as proportion of migrants in population from BayesAss (BA) and estimated as number of migrants per generation $\left(N_{m}\right)$ from Migrate-N $(\mathrm{M})$ with estimated migration rate in parentheses. Rates in bold significant at $p=0.05$. Pairwise $F_{\mathrm{ST}}$ shown in lower diagonal.

\begin{tabular}{ccccccc}
\hline In & From & Cádiz & Almería & Huelva & Córdoba & Seville \\
\hline \multirow{2}{*}{ Cádiz } & BA & 0.91 & 0.02 & 0.02 & 0.02 & 0.03 \\
& $\mathrm{M}$ & - & $27.2(0.14)$ & $26.1(0.13)$ & $21.9(0.11)$ & $18.7(0.09)$ \\
\hline \multirow{3}{*}{ Almería } & $\mathrm{BA}$ & 0.03 & 0.68 & 0.02 & $\mathbf{0 . 2 6}$ & 0.02 \\
& $\mathrm{M}$ & $23.9(0.12)$ & - & $22.5(0.11)$ & $23.9(0.12)$ & $34.8(0.17)$ \\
& $F_{\mathrm{ST}}$ & 0.07 & - & - & - & - \\
\hline \multirow{3}{*}{ Huelva } & $\mathrm{BA}$ & 0.02 & 0.02 & 0.68 & $\mathbf{0 . 2 6}$ & 0.02 \\
& $\mathrm{M}$ & $26.5(0.13)$ & $26.5(0.13)$ & - & $20.4(0.10)$ & $105.5(0.53)$ \\
& $F_{\mathrm{ST}}$ & 0.06 & 0.05 & - & - & - \\
\hline \multirow{3}{*}{ Córdoba } & $\mathrm{BA}$ & 0.05 & 0.02 & 0.02 & 0.89 & 0.02 \\
& $\mathrm{M}$ & $1.2(0.01)$ & $1.0(0.01)$ & $4.2(0.02)$ & - & $4.8(0.02)$ \\
& $F_{\mathrm{ST}}$ & 0.07 & 0.06 & 0.04 & - & - \\
\hline \multirow{2}{*}{ Seville } & $\mathrm{BA}$ & 0.06 & 0.02 & 0.02 & $\mathbf{0 . 1 2}$ & 0.79 \\
& $\mathrm{M}$ & $37.2(0.19)$ & $30.2(0.15)$ & $29.7(0.15)$ & $23.0(0.12)$ & - \\
& $F_{\mathrm{ST}}$ & 0.07 & 0.06 & 0.04 & 0.04 & - \\
\hline
\end{tabular}

Estimates of evolutionary among-population migration rates (number of migrants per generation $N_{m}$ ) were calculated from Migrate-N estimates of $\theta$ and $M$ as $N_{m}=(\theta \times M) / 4$ (Table 3). The highest rate $\left(N_{m}=105.5\right)$ was from Seville to Huelva, approximately 3 times greater than the next highest rates from Cádiz to Seville $\left(N_{m}=37.2\right)$ and Seville to Almería $\left(N_{m}=34.8\right)$. Migration rates were asymmetrical for several population pairs; notably, Córdoba was much more important as a source than as a sink population.

Comparisons of Bayes factors from Migrate- $\mathrm{N}$ for the different phylogeographic breaks supported a two-group model (Cádiz and (Almería, Huelva, Seville, Córdoba)).

\section{Discussion}

\subsection{Population Structure}

Chloroplast DNA showed relatively strong spatial structure; only populations at Seville and Huelva shared haplotypes. Because chloroplast DNA is maternally inherited in oaks, it is dispersed only by seed; thus our results were consistent with the bulk of seed dispersal being limited locally or to adjacent habitat for Q. ilex [41-45], for other oak species [46-48], and for the acorn-bearing tanoak [49]. We found no evidence of shared haplotypes among other population pairs, but we could infer at least two examples of probable long-distance dispersal that would have occurred for generations in the past. In these instances, one individual from each of Cádiz and Córdoba had haplotypes that clustered with the Huelva/Seville group, which would suggest past seed dispersal from Seville/Huelva to Córdoba and to Cádiz. Our data, using a suite of chloroplast microsatellite markers, detected fine-scale haplotype variation that had not been detected in earlier studies using less variable markers. For example, Lumaret et al. [23] reported only 25 haplotypes (on the basis of PCR-RFLP markers) throughout the entire range of $Q$. ilex and 3 within southeastern Spain, compared with the 30 that we detected in Andalusia. Our nuclear DNA showed a much weaker spatial structure 
(differentiation among populations) than the chloroplast DNA. This was expected because of the smaller effective population size of chloroplast DNA and because of wind pollination leading to much more widespread gene dispersal. Nevertheless, we found evidence of nuclear genetic structure among populations of $Q$. ilex in Andalusia. We used several approaches to investigate potential breaks. The STRUCTURE and DAPC analyses suggested weak genetic structure partitioned into three groups; Cádiz, Almería, and Sierra Morena populations (Seville, Huelva, and Córdoba). However, this partition was not supported by inferred contemporary (BayesAss) or evolutionary-scale migration rates (Migrate-N). The most consistent break suggested by the migration rate analyses was between Cádiz and the more northern populations of Huelva, Seville, and Córdoba. This suggests that the Guadalquivir Basin, where Q. ilex is absent, has presented a "recent" barrier to gene flow between the southern Cordillera Subbética and the Sierra Morena. The Guadalquivir Valley likely served as a refugium during the full glacial period, but early human deforestation of the valley may have broken continuity between the northern and southern populations [50,51]. Divergence among plant populations of the southern Iberian mountains likely has diverse origins. Fortuna et al. [52], using a comparative network approach to study genetic variation among four woody species from southern Spain, found that each species had responded to ancient landscape processes rather than more recent events and in unique ways. For all species, divergence across the Guadalquivir Valley was significant, although $Q$. coccifera L. showed least population structure, likely related to unique life history traits. In some instances, the Gudalquivir divergence may be associated with closer affinities of Baetic populations to those of North Africa, as is the case for Erophaca baetica (L.) Boiss. [53] and the aster Hypochaeris radicata L. [54].

We found no consistent break within the Baetic Cordillera, despite the population in Almería being in the Mediterranean coastal range and the population of Cádiz being in the inner mountain range of the Cordillera Subbética. This could reflect connectivity through a low-medium mountain corridor until very recent times [55-59]. Our Barrier analyses also found the strongest break to be between Cádiz and the Sierra Morena, with a second break that was non-significant between Cádiz and Almería.

\subsection{Gene Flow}

Fragmentation of populations in the recent past due to human activity may result in reduced levels of gene flow. The long-term effects of limited gene flow will be reduced genetic variability that is commonly assumed to lead to reduced population viability [60]. BayesAss estimates recent migration rates ( $<5$ generations) that would be in the time-frame of human activity in the Spanish dehesas [61,62]. On the other hand, Migrate-N uses a coalescence approach that infers migration rates over the last $4 N_{e}$ generations [63], which, in $Q$. ilex, would likely cover the last tens of thousands of years and so would be affected mostly by events not associated with human activity. However, prehistoric human activities could have played a role in vegetation changes in the Guadalquivir Valley associated with fire, change of species, and scrubbing [64]. To compare the two estimates of migration, we converted the mutation-scaled migration rate $(M=m / \mu)$ from Migrate-N by multiplying $M$ by an estimated mutation rate $\mu$ of $5 \times 10^{-4}$ [65], following the approach described by Chiucchi and Gibbs [66]. Our estimates of recent migration from BayesAss indicate low levels of migration among population pairs, except for unidirectional immigration from Córdoba to Almería, Huelva, and Seville. After transformation, evolutionary migration rates were about an order of magnitude greater than recent migration rates. Although this would be consistent with reduced gene flow among populations since human activity began in the dehesas, the results should be treated with caution. A change in the mutation rate has an important effect on the estimates of migration rates based on mutation-scaled migration rates. Assuming a mutation rate of $1 \times 10^{-4}$ would bring many of the evolutionary rates close to the contemporary rates. However, reduced contemporary migration may reflect, in part, the management regime of the dehesas that has been based on the existing forest and not on the establishment of new forests [67]. 
Contemporary patterns of migration among populations showed some similarities and some contrasts with patterns of evolutionary rates. Notably, we found a strong asymmetry between immigration rates into Córdoba and immigration into other populations from Córdoba for both contemporary and evolutionary migration. Flowering phenology could explain some of this asymmetry. In $Q$. ilex, most inflorescences are protandrous, and flowering phenology is earlier at warmer lower elevations [68]. The Córdoba population has the most continental climate of all populations studied, and thus its winters are significantly colder [5,69]. The Córdoba population would likely be more successful at pollinating receptive female flowers from lower elevations, such as Huelva and Seville, because of the overlapping of male and female phenology, whereas the reverse direction would lead to a greater dispersion between male and female flowering times. The most pronounced difference between contemporary and evolutionary migration rates was between Seville and Huelva. As expected, evolutionary rates were highest between this closest population pair, but contemporary rates were low in both directions. Without a doubt, these populations have been the most disturbed by human activity in historical times [70,71].

\subsection{Association between Phenotypic Traits and Population Divergence}

Does the phenotypic variability and the population grouping derived from this variability reflect the genetic structure of the Andalusian $Q$. ilex as determined by $n$ - and cp-SSR? In a previous study on seed morphometry and fatty acid composition, 13 populations from 3 main geographical areas (southern, northeastern, and northwestern provenances) were grouped into 2 main clusters, with the Guadalquivir as a hypothetical frontier separating them [11]. The first cluster corresponded to northern, mesic, low-altitude provenances, while the second corresponded to southern, xeric, high-altitude provenances. Protein profiles from seed and pollen, as determined by NIRS and one-dimensional gel electrophoresis, reinforced relationships among populations being related to geographic location and climatic zone [10]. Geographically extreme provenances were clearly included in the northern (Sierra Morena) or southern (Baetic Cordillera) clusters, independently of the method employed [10-12]. However, interestingly, depending on the methodology employed, some provenances were grouped in different clusters. This was the case for those provenances that were closest to the Guadalquivir Valley (southern margins of the Sierra Morena and northern margins of the Baetic range). It would therefore appear that the morphological and biochemical structuring are in fairly good agreement with the structuring obtained using our neutral genetic markers. This does not imply any causality, for which we would need to prove a genetic basis of the phenotypic traits and look for variation in functional genes that might explain any potential environmental adaptations. The phenotypic variation that we observed could be related to environmental variation, such as xeric stress, that is presumably only indirectly related to variability in microsatellite markers. Nevertheless, it is interesting that the genetic and phenotypic partitioning of populations showed some concordance that justifies more rigorous tests, such as comparative tests across aridity gradients in each of the major regions.

Our genetic data suggest moderately important variation that should be taken into consideration in any reforestation of $Q$. ilex in Andalusia. Reforestation north of the Guadalquivir Valley should be from seed sources of that region, particularly as there may be growth-related adaptive traits for the more mesic conditions that we have not yet tested. In the south, we consider that it would be prudent to use local sources for eastern and western reforestation as the genetic data suggests some divergence in this region.

\section{Conclusions}

We used genetic markers (chloroplast and nuclear microsatellites) to detect structure among populations of $Q$. ilex from the major biogeographic regions of Andalusia. Our results show surprisingly important levels of genetic structure, with chloroplast DNA indicating little gene exchange as a result of seed dispersal among populations. Our nuclear DNA analyses showed a weaker but significant genetic structure among populations, presumably as a result of more widespread pollen 
dispersal and the larger effective population size of nuclear DNA. We used several approaches to identify the most consistent breaks among populations and to infer recent and evolutionary migrations rates. The population from the Baetic Cordillera (Cádiz) consistently appeared well separated from populations of the northern Sierra Morena, suggesting that the Guadalquivir Valley has played an important role in determining population divergence. This may be, in part, evolutionary, as suggested by chloroplast DNA, and, in part, a result of human-induced population isolation, as $Q$. ilex has been removed from the Guadlaquivir Valley. Whereas the relatively isolated population from Almería was well separated from Cádiz, it appeared to show some connectivity with Córdoba, the easternmost population of the Sierra Morena. Our gene flow estimates suggest that evolutionary rates were greater than contemporary rates of migration. Furthermore, contemporary rates were limited to unidirectional gene flow from Córdoba to other populations in the Sierra Morena and, surprisingly, to the southern population at Almería. The inconsistency between evolutionary and recent migrations rates suggests an effect of anthropogenic activity over the last few generations of $Q$. ilex. Our population structure from genetic data was more or less consistent with our earlier partitioning of populations on the basis of phenotypic and biochemical variability, but this association may simply reflect environmentally induced phenotypic variation. We will need to continue this work to look at the genetic basis of the phenotypic traits and the role of functional genes.

Supplementary Materials: The following are available online at http:/ /www.mdpi.com/1999-4907/9/6/337/s1, Figure S1: Mode-shift distributions of numbers of alleles at different allele frequencies in the five populations studied in this work, Figure S2: BARRIER plot of 5 populations of $Q$. ilex from Andalusia showing the first 3 significant barriers. Thickness of line indicates strength of barrier: 1-Cádiz, 2-Almería, 3-Huelva, 4-Córdoba, 5-Seville, Figure S3: Andalusia map showing the location of the populations studied in this work and geographic information (A: altitude, B: annual rainfall and C: dryness index), Table S1: Names and characteristics of the nuclear nSSR and chloroplast cpSSR microsatellite markers used for genotyping [72-76].

Author Contributions: A.F.i.M., J.V.J.-N., and R.S.D. designed the study. A.F.i.M., C.R.-R., and N.A. performed the molecular experiments. R.S.D. conducted the statistical analysis. J.V.J.-N. obtained the funds for the research. A.F.i.M., J.V.J.-N., R.M.N.-C., and R.S.D. participated in the writing and editing of the manuscript. A.F.i.M. and C.R.-R. contributed equally in this work.

Funding: This work is part of the ENCINO-OMICA (BIO2015-64737-R2) and ESPECTRAMED (CGL2017-86161-R) projects. Thanks are given to the University of Cordoba and Spanish Ministry of Economy and Competitiveness for financial support.

Conflicts of Interest: The authors declare no conflict of interest.

\section{References}

1. Moreno, G.; Pulido, F.J. The functioning, management and persistence of dehesas. In Agroforestry in Europe; Springer: Dordrecht, The Netherland, 2009; pp. 127-160.

2. Brasier, C.M.; Robredo, F.; Ferraz, J.F.P. Evidence for Phytophthora cinnamomi involvement in Iberian oak decline. Plant Pathol. 1993, 42, 140-145. [CrossRef]

3. Sghaier-Hammami, B.; Valero Galvàn, J.; Romero-Rodríguez, C.; Navarro-Cerrillo, R.M.; Abdelly, C.; Jorrín-Novo, J. Physiological and proteomics analyses of Holm oak Quercus ilex subsp. ballota [Desf.] Samp. responses to Phytophthora cinnamomi. Plant Physiol. Biochem. 2013, 71, 191-202. [CrossRef] [PubMed]

4. Pulido, F.J.; Díaz, M.; Hidalgo de Trucios, S.J. Size structure and regeneration of Spanish holm oak Quercus ilex forests and dehesas: Effects of agroforestry use on their long-term sustainability. For. Ecol. Manag. 2001, 146, 1-13. [CrossRef]

5. Barbeta, A.; Peñuelas, J. Sequence of plant responses to droughts of different timescales: Lessons from holm oak Quercus ilex forests. Plant Ecol. Divers. 2016, 9, 321-338. [CrossRef]

6. MAPA. Forestación de Tierras Agrícolas; Ministerio de Agricultura y Pesca: Madrid, Spain, 2006.

7. Valero Galván, J.; González Fernandez, R.; Navarro Cerrillo, R.M.; Pelegrín, E.G.; Jorrín-Novo, J.V. Physiological and Proteomic Analyses of Drought Stress Response in Holm Oak Provenances. J. Proteome Res. 2013, 12, 5110-5123. [CrossRef] [PubMed] 
8. Corcobado, T.; Cubera, E.; Juárez, E.; Moreno, G.; Solla, A. Drought events determine performance of Quercus ilex seedlings and increase their susceptibility to Phytophthora cinnamomi. Agric. For. Meteorol. 2014, 192, 1-8. [CrossRef]

9. Corcobado, T.; Miranda-Torres, J.J.; Martín-García, J.; Jung, T.; Solla, A. Early survival of Quercus ilex subspecies from different populations after infections and coinfections by multiple Phytophthora species. Plant Pathol. 2017, 665, 792-804. [CrossRef]

10. Valero Galván, J.; Valledor, L.; Cerrillo, R.M.N.; Pelegrín, E.G.; Jorrín-Novo, J.V. Studies of variability in Holm oak Quercus ilex subsp. ballota [Desf.] Samp. through acorn protein profile analysis. J. Proteom. 2011, 74, 1244-1255. [CrossRef] [PubMed]

11. Valero Galván, J.; Jorrín-Novo, J.; Cabrera, A.; Ariza, D.; García-Olmo, J.; Cerrillo, R. Population variability based on the morphometry and chemical composition of the acorn in Holm oak Quercus ilex subsp. ballota [Desf.] Samp. Eur. J. For. Res. 2012, 131, 893-904. [CrossRef]

12. Valero Galván, J.; Valledor, L.; González Fernandez, R.; Navarro Cerrillo, R.M.; Jorrín-Novo, J.V. Proteomic analysis of Holm oak Quercus ilex subsp. ballota [Desf.] Samp. pollen. J. Proteom. 2012, 75, 2736-2744. [CrossRef] [PubMed]

13. Guzmán, B.; Rodríguez-López, C.M.; Forrest, A.; Cano, E.; Vargas, P. Protected areas of Spain preserve the neutral genetic diversity of Quercus ilex L. irrespective of glacial refugia. Tree Genet. Genom. 2015, 11, 124. [CrossRef]

14. Vitelli, M.; Vessella, F.; Cardoni, S.; Pollegioni, P.; Denk, T.; Grimm, G.W.; Simeone, M.C. Phylogeographic structuring of plastome diversity in Mediterranean oaks (Quercus Group Ilex, Fagaceae). Tree Genet. Genom. 2017, 13, 3. [CrossRef]

15. Hewitt, G.M. Genetic consequences of climatic oscillations in the Quaternary. Philos. Trans. R. Soc. B 2004, 359, 183-195. [CrossRef] [PubMed]

16. Taberlet, P.; Fumagalli, L.; Wust-Saucy, A.G.; Cosson, J.F. Comparative phylogeography and postglacial colonization routes in Europe. Mol. Ecol. 1998, 7, 453-464. [CrossRef] [PubMed]

17. Ortego, J.; Bonal, R.; Muñoz, A. Genetic consequences of habitat fragmentation in long-lived tree species: The case of the Mediterranean Holm Oak (Quercus ilex, L.). J. Hered. 2010, 101, 717-726. [CrossRef] [PubMed]

18. Gómez, A.; Lunt, D.H. Refugia within refugia: Patterns of phylogeographic concordance in the Iberian Peninsula. In Phylogeography of Southern European Refugia: Evolutionary Perspectives on the Origins and Conservation of European Biodiversity; Weiss, S., Ferrand, N., Eds.; Springer: Berlin, Germany, 2007; pp. 155-188.

19. Sinclair, W.T.; Morman, J.D.; Ennos, R.A. The postglacial history of Scots pine (Pinus sylvestris L.) in Western Europe: Evidence from mitochondrial DNA variation. Mol. Ecol. 1999, 8, 83-88. [CrossRef]

20. Soranzo, N.; Alia, R.; Provan, J.; Powell, W. Patterns of variation at a mitochondrial sequence-tagged-site locus provides new insights into the postglacial history of European Pinus sylvestris populations. Mol. Ecol. 2000, 9, 1205-1211. [CrossRef] [PubMed]

21. Petit, R.J.; Csaikl, U.; Bordacs, S.; Burg, K.; Coart, E.; Cottrell, J.; Van Dam, B.; Deans, J.; Dumolin-Lapegue, S.; Fineschi, S.; et al. Chloroplast DNA variation in European white oaks: Phylogeography and patterns of diversity based on data from over 2600 populations. For. Ecol. Manag. 2002, 156, 5-26. [CrossRef]

22. González-Martinez, S.C.; Gómez, A.; Carrión, J.S.; Agúndez, D.; Alía, R.; Gil, L. Spatial genetic structure of an explicit glacial refugium of maritime pine Pinus pinaster Aiton in southeastern Spain. In Phylogeography of Southern European Refugia: Evolutionary Perspectives on the Origins and Conservation of European Biodiversity; Weiss, S., Ferrand, N., Eds.; Springer: Berlin, Germany, 2007; pp. 257-269.

23. Lumaret, R.; Mir, C.; Michaud, H.; Raynal, V. Phylogeographical variation of chloroplast DNA in Holm Oak (Quercus ilex L.). Mol. Ecol. 2002, 11, 2327-2336. [CrossRef] [PubMed]

24. Jennings, R.; Finlayson, C.; Fa, D.; Finlayson, G. Southern Iberia as a refuge for the last Neanderthal populations. J. Biogeogr. 2011, 38, 1873-1885. [CrossRef]

25. Jorrín-Novo, J.V.; Pascual, J.; Lucas, R.S.; Romero-Rodriguez, C.; Ortega, M.R.; Lenz, C.; Valledor, L. Fourteen years of plant proteomics reflected in "Proteomics": Moving from model species and 2-DE based approaches to orphan species and gel-free platforms. Proteomics 2015, 15, 1089-1112. [CrossRef] [PubMed]

26. Echevarria-Zomeno, S.; Ariza, D.; Jorge, I.; Lenz, C.; Del Campo, A.; Jorrin, J.V.; Navarro, R.M. Changes in the protein profile of Quercus ilex leaves in response to drought stress and recovery. J. Plant Physiol. 2009, 166, 233-245. [CrossRef] [PubMed] 
27. Bandelt, H.J.; Forster, P.; Röhl, A. Median-joining networks for inferring intraspecific phylogenies. Mol. Biol. Evol. 1999, 16, 37-48. [CrossRef] [PubMed]

28. Polzin, T.; Daneschmand, S.V. On Steiner trees and minimum spanning trees in hypergraphs. Oper. Res. Lett. 2003, 31, 12-20. [CrossRef]

29. Wang, C.; Schroeder, K.B.; Rosenberg, N.A. A maximum-likelihood method to correct for allelic dropout in microsatellite data with no replicate genotypes. Genetics 2012, 192, 651-669. [CrossRef] [PubMed]

30. Goudet, J. FSTAT: A Program to Estimate and Test Gene Diversities and Fixation Indices (Version 2.9.3.2). 2002. Available online: https: / www.scienceopen.com / document?vid=79097bb4-ec3c-47c3-94a1-47085d721e6b (accessed on 15 January 2018).

31. Piry, S.; Luikart, G.; Cornuet, J.M. Bottleneck: A computer program for detecting recent reductions in the effective population size using allele frequency data. J. Hered. 1999, 90, 502-503. [CrossRef]

32. Pritchard, J.K.; Stephens, M.; Donnelly, P. Inference of population structure using multilocus genotype data. Genetics 2000, 155, 945-959. [PubMed]

33. Jombart, T.; Devillard, S.; Balloux, F. Discriminant analysis of principal components: A new method for the analysis of genetically structured populations. BMC Genet. 2010, 11, 94. [CrossRef] [PubMed]

34. Evanno, G.; Regnaut, S.; Goudet, J. Detecting the number of clusters of individuals using the software STRUCTURE: A simulation study. Mol. Ecol. 2005, 14, 2611-2620. [CrossRef] [PubMed]

35. Kopelman, N.M.; Mayze, J.L.; Jakobsson, M.; Rosenberg, N.A.; Mayrose, A. Clumpak: A program for identifying clustering modes and packaging population structure inferences across K. Mol. Ecol. Resour. 2015, 15, 1179-1191. [CrossRef] [PubMed]

36. Manni, F.; Guérard, E.; Heyer, E. Geographic patterns of genetic, morphologic, linguistic variation: How barriers can be detected by “Monmonier's algorithm". Hum. Biol. 2004, 762, 173-190. [CrossRef]

37. Dieringer, D.; Schlötterer, C. Microsatellite analyser MSA: A platform independent analysis tool for large microsatellite data sets. Mol. Ecol. Notes 2003, 3, 167-169. [CrossRef]

38. Wilson, G.A.; Rannala, B. Bayesian Inference of Recent Migration Rates Using Multilocus Genotypes. Genetics 2003, 163, 1177-1191. [PubMed]

39. Rambaut, A.; Drummond, A.J. Tracer v1.4. 2007. Available online: http://tree.bio.ed.ac.uk/software/tracer/ (accessed on 15 January 2018).

40. Cornuet, J.M.; Luikart, G. Description and power analysis of two tests for detecting recent population bottlenecks from allele frequency data. Genetics 1996, 144, 2001-2014. [PubMed]

41. Gómez, J.M. Spatial patterns in long distance dispersal of Quercus ilex acorns by jays in a heterogeneous landscape. Ecography 2003, 26, 573-584. [CrossRef]

42. Gómez, J.M.; Valladares, F.; Puerta-Piñero, C. Differences between structural and functional environmental heterogeneity caused by seed dispersal. Funct. Ecol. 2004, 18, 787-792. [CrossRef]

43. Soto, A.; Lorenzo, Z.; Gil, L. Differences in fine-scale genetic structure and dispersal in Quercus ilex L. and $Q$. suber L.: Consequences for regeneration of Mediterranean open woods. Heredity 2007, 99, 601-607. [CrossRef] [PubMed]

44. Smit, C.; Díaz, M.; Jansen, P. Establishment limitation of holm oak Quercus ilex subsp. ballota Desf. Samp. in a Mediterranean savanna-forest ecosystem. Ann. For. Sci. 2009, 66, 1-7. [CrossRef]

45. García-Nogales, A.; Linares, J.C.; Laureano, R.G.; Seco, J.I.; Merino, J. Range wide variation in life history phenotypes: Spatiotemporal plasticity across the latitudinal gradient of the evergreen oak Quercus ilex. J. Biogeogr. 2016, 4312, 2366-2379. [CrossRef]

46. Le Corre, V.; Machon, N.; Petit, R.J.; Kremer, A. Colonization with long-distance seed dispersal and genetic structure of maternally inherited genes in forest trees: A simulation study. Genet. Res. 1997, 69, 117-125. [CrossRef]

47. Grivet, D.; Smouse, P.E.; Sork, V.L. A novel approach to an old problem: Tracking dispersed seeds. Mol. Ecol. 2005, 14, 3585-3595. [CrossRef] [PubMed] 
48. Dodd, R.S.; Afzal-Rafii, Z.; Mayer, W. Molecular markers show how pollen and seed dispersal affect population genetic structure in coast live oak Quercus agrifolia Née. In Proceedings of the Sixth Symposium on Oak Woodlands: Today's Challenges, Tomorrow's Opportunities; Merenlender, A., McCreary, D., Purcell, K.L., Eds.; PSW-GTR-217; US Department of Agriculture, Forest Service, Pacific Southwest Research Station: Albany, CA, USA, 2008; pp. 485-495.

49. Nettel, A.; Dodd, R.S.; Afzal-Rafii, Z. Genetic diversity, structure, and demographic change in tanoak, Lithocarpus densiflorus Fagaceae, the most susceptible host to the Sudden Oak Death disease in California. Am. J. Bot. 2009, 96, 2224-2233. [CrossRef] [PubMed]

50. Aparicio, A. Descriptive analysis of the 'relictual'Mediterranean landscape in the Guadalquivir River valley southern Spain: A baseline for scientific research and the development of conservation action plans. Biodivers. Conserv. 2008, 17, 2219-2232. [CrossRef]

51. Carrión-Marco, Y.; Ntinou, M.; Badal, E. Neolithic woodland in the north Mediterranean basin: A review on Olea europaea L. In Proceedings of the Fourth International Meeting of Anthracology; Damblon, F., Ed.; Series 2486; Archaeo Press: Oxford, UK, 2013.

52. Fortuna, M.A.; Albaladejo, R.G.; Fernández, L.; Aparicio, A.; Bascompte, J. Networks of spatial genetic variation across species. Proc. Natl. Acad. USA 2009, 106, 19044-19049. [CrossRef] [PubMed]

53. Casimiro-Soriguer, R.; Talavera, M.; Balao, F.; Terrab, A.; Herrera, J.; Talavera, S. Phylogeny and genetic structure of Erophaca (Leguminosae), a East-West Mediterranean disjunct genus from the Tertiary. Mol. Phylogenet. Evol. 2010, 56, 441-450. [CrossRef] [PubMed]

54. Ortiz, M.Á.; Tremetsberger, K.; Terrab, A.; Stuessy, T.F.; García-Castaño, J.L.; Urtubey, E.; Baeza, C.M.; Ruas, C.F.; Gibbs, P.E.; Talavera, S. Phylogeography of the invasive weed Hypochaeris radicata (Asteraceae): From Moroccan origin to worldwide introduced populations. Mol. Ecol. 2008, 17, 3654-3667. [CrossRef] [PubMed]

55. Carrión, J.S.; Sánchez-Gómez, P.; Mota, J.F.; Yll, R.; Chaín, C. Holocene vegetation dynamics, fire and grazing in the Sierra de Gádor, southern Spain. Holocene 2003, 13, 839-849. [CrossRef]

56. Carrion, J.S.; Yll, E.I.; Walker, M.J.; Legaz, A.J.; Chain, C.; Lopez, A. Glacial refugia of temperate, Mediterranean and Ibero North African flora in south-eastern Spain: New evidence from cave pollen at two Neanderthal man sites. Glob. Ecol. Biogeogr. 2003, 12, 119-129. [CrossRef]

57. Carrión, J.S.; Fernández, S.; Jiménez-Moreno, G.; Fauquette, S.; Gil-Romera, G.; González-Sampériz, P.; Finlayson, C. The historical origins of aridity and vegetation degradation in southeastern Spain. J. Arid Environ. 2010, 74, 731-736. [CrossRef]

58. Carrión, J.S.; Fernández, S.; González-Sampériz, P.; Gil-Romera, G.; Badal, E.; Carrión-Marco, Y.; López-Merino, L.; López-Sáez, J.A.; Fierro, E.; Burjachs, F. Expected trends and surprises in the Lateglacial and Holocene vegetation history of the Iberian Peninsula and Balearic Islands. Rev. Palaeobot. Palynol. 2010, 162, 458-475. [CrossRef]

59. Gil-Romera, G.; Carrion, J.S.; Pausas, J.G.; Seville-Callejo, M.; Lamb, H.F.; Burjachs, F. Holocene fire activity and vegetation response in South-Eastern Iberia. Quat. Sci. Rev. 2010, 29, 1082-1092. [CrossRef]

60. Frankham, R.; Lees, K.; Montgomery, M.E.; England, P.R.; Lowe, E.; Briscoe, D.A. Do population size bottlenecks reduce evolutionary potential? Anim. Conserv. 1999, 2, 255-260. [CrossRef]

61. Plieninger, T.; Pulido, F.J.; Schaich, H. Effects of land-use and landscape structure on holm oak recruitment and regeneration at farm level in Quercus ilex L. dehesas. J. Arid Environ. 2004, 57, 345-364. [CrossRef]

62. Geri, F.; Amici, V.; Rocchini, D. Human activity impact on the heterogeneity of a Mediterranean landscape. Appl. Geogr. 2010, 30, 370-379. [CrossRef]

63. Beerli, P. Migrate Version 3.0: A Máximum Likelihood and Bayesian Estimator of Gene Flow Using the Coalescent. 2008. Available online: http:/ / popgen.scs.edu/migrate.html (accessed on 15 January 2018).

64. Rodríguez-Ariza, M.O. Vegetation evolution and use during prehistory in the upper Guadalquivir. In MENGA 02. Journal of Andalusian Prehistory; Junta de Andalucia: Malaga, Spain, 2011.

65. Garza, J.C.; Williamson, E.G. Detection of reduction in population size using data from microsatellite loci. Mol. Ecol. 2001, 10, 305-318. [CrossRef] [PubMed]

66. Chiucchi, J.E.; Gibbs, H.L. Similarity of contemporary and historical gene flow among highly-fragmented populations of an endangered rattlesnake. Mol Ecol. 2010, 19, 5345-5348. [CrossRef] [PubMed]

67. Vicente, A.M.; Alés, R.F. Long term persistence of dehesas. Evidences from history. Agrofor. Syst. 2006, 67, 19-28. [CrossRef] 
68. Gómez-Casero, M.T.; Galán, C.; Domínguez-Vilches, E. Flowering phenology of Mediterranean Quercus species in different locations Córdoba, SW Iberian Peninsula. Acta Bot. Malacit. 2007, 32, 127-146.

69. Felicísimo, A.M.; Muñóz, J.; Mateo, R.; Villalba, C.J. Vulnerabilidad de la flora y vegetación españolas ante el cambio climático. Ecosistemas 2012, 21, 1-6.

70. Sáez, J.L.; García, P.L.; Sánchez, M.M. Análisis palinológico del yacimiento arqueológico de Pocito Chico El Puerto de Santa María: El paisaje prehistórico y protohistórico durante el Holoceno reciente en las Marismas de Cádiz. Cuaternario y Geomorfología 2001, 15, 45-59.

71. Pérez-Jordà, G.; Peña-Chocarro, L.; Fernández, M.G.; Rodríguez, J.V. The beginnings of fruit tree cultivation in the Iberian Peninsula: Plant remains from the city of Huelva southern Spain. Veg. History Archaeobot. 2017, 26, 527-538. [CrossRef]

72. Dow, B.D.; Ashley, M.V.; Howe, H.F. Characterization of highly variable (GA/CT)n microsatellites in the bur oak, Quercus macrocarpa. Theor. Appl. Genet. 1995, 91, 137-141. [CrossRef] [PubMed]

73. Kampfer, S.; Lexer, C.; Glöss, J.; Steinkellner, H. Characterization of (GA)n microsatellite loci from Quercus robur. Hereditas 1998, 129, 183-186. [CrossRef]

74. Steinkellner, H.; Fluch, S.; Turetscheck, E.; Lexer, C.; Streiff, R.; Kremer, A.; Burg, K.; Gloss, J. Identification and characterization of (GA/CT) -Microsatellite loci from Quercus petraea. Plant Mol. Biol. 1997, 33, 1093-1096. [CrossRef] [PubMed]

75. Sebastiani, L.; Scebba, F.; Tognetti, R. Heavy metal accumulation and growth responses in poplar clones Eridano (Populus deltoides $\times$ maximowiczii) and I.-214 $($ P. $\times$ euramericana) exposed to industrial waste. Environ. Exp. 2004, 52, 79-88. [CrossRef]

76. Deguilloux, M.F.; Pemonge, M.H.; Petit, R.J. Use of chloroplast microsatellites to differentiate oak populations. Ann. For. Sci. 2004, 61, 825-830. [CrossRef]

(C) 2018 by the authors. Licensee MDPI, Basel, Switzerland. This article is an open access article distributed under the terms and conditions of the Creative Commons Attribution (CC BY) license (http:// creativecommons.org/licenses/by/4.0/). 